高分子論文集 (Kobunshi Ronbunshu), Vol. 32, No. 4, pp. 229-234 (Apr., 1975)

\title{
乳化剂不在下でのポリアクリル酸エチルエマルジョン の合成とその皮膜の耐水性*
}

\author{
松本 恒隆*1 $\cdot$ 大久保 政芳*1 $\cdot$ 今井 正*1
}

(受付 1974 年 11 月 16 日・雷査終了 1975 年 1 月 8 日)

\begin{abstract}
要 旨 乳化剂不在下での過硫酸カリウム (KPS) を開始凨として得られたポリアクリル酸エチル (PEA) エマルジョンの安定化条件とその皮膜の耐水性との関倸について検討し, 次の結果を得た. 1) 重合安定性および放置安定性の良好なエマルジョンは最適 KPS 浱度 (本実験では約 $120 \mathrm{mg} / l$ ) に扔いて作製された，2）粒子表面上には，粒子中のポリマー分子数に相当する $-\mathrm{SO}_{4}-$ 基が存在し た，3）同一 KPS 濃度においては，重合温度が高くなるほど粒子は安定であった。4) 得られた無乳 化剤エマルジョン皮膜は乳化剤含有のものに比べて著しく耐水性は良好であった。 5) KPS 濃度が高 くなるほど, 耐水性は低下した。同一濃度では, 重合温度が高いものほど耐水性はよかった，以上の 諸結果加 由来する電解質を減少させることにより, 耐水性皮膜を与える安定な無乳化剂 PEA エマルジョンの 作製できる可能性が明らかにされた。
\end{abstract}

\section{1 緒言}

これまで接着剤および塗料の分野では，有機溶剤を蒸 発させ, 皮膜化して用いる, いわゆる溶液型のものが主と して用いられてきた。しかし，溶剤が毒性，火災源にな ることに加え，大気および水質污染，原油の高騰による 省資源化の問題が加わり, 今後, これらの問題をすべて 解決するとみなされる水媒体エマルジョン型への移行が 急務とされている，ところで，高分子ェマルジョンは乳 化重合で作製されるが，この際用いられる乳化剂は，重 合の場の提供, エマルジョン粒子の安定化に働き，不可 欠である。しかしながら，エマルジョンを皮膜化した場 合, 乳化剂は皮膜中に残存し, その耐水性を極度に低下 させる.このことが，エマルジョン型への移行を妨げて いた主原因であった。ささらには, 近年ェマルジョン廃水 中の乳化剤が公害源としてとりあげられる傾向にあり, したがって，乳化剂を含有しない高分子エマルジョンが 種々検討される段階になってきた。 この場合, 特に問題 となるのはェマルジョン粒子の安定化である. 著者らは この点に関してすで開始剤として過硫酸カリウムを用 いた場合, 乳化剂を存在させなくても比較的安定なポリ スチレンェマルショョンが作製され，そして，それが開始 鼡切片として粒子表面にの及存在する $-\mathrm{SO}_{4}$ - 基による ことを明らかにした1).

* 本報を「サスペンジョンおよびェマルジョンに関す る研究 第 22 報」とする

*1 神戸大学工学部工業化学教室 (于657 神戸市灘区六 甲台町 1)
本報では，このような知見に基づき，乳化剤を用いな いでアアクリル酸エチルの乳化重合を過硫酸カリウムを 開始剤として行い, 安定なエマルジョンを作製する条件 を明確にするとともに，その皮膜の耐水性を検討するこ とから，無公害性の無乳化剂高分子ェマルジョンに関す る基本的性質を明らかにしようとした。

\section{2 実験方法}

\section{1 試料}

モノマーとしてのアクリル酸エチル (EA) は，常法 により蒸留精製した，開始剤としての過硫酸カリウム (KPS) およびアニオン性界面活性剤であるラウリル硫 酸ナトリウム(SLS) は，それぞれ再結晶法により精製 したものを, 水は比抵抗 $5 \times 10^{6} \Omega \cdot \mathrm{cm}$ のイオン交換水 を用いた。

\section{2 乳化重合}

$300 \mathrm{ml}$ の四つロフラスコ中に, 水 $140 \mathrm{~m} l, \mathrm{EA} 60$ $\mathrm{m} l$, および所定量の KPS (mg/l で表示) を仕込み, 窒 素気流中，かき混ぜ速度 $250 \mathrm{rpm}$ (ねじり型かくはん 棒) で，重合率が $98 \%$ 以上になるまで行った。なお， 重合温度は特に記載しない限り $70^{\circ} \mathrm{C}$ である。

\section{3 エマルジョンの安定性}

重合安定性は，全ポリマー量に対する重合時に発生す るゲル物量の割合で表示した，放置安定性は $18 \mathrm{~mm}$ 径 の試䥐管中に試料エマルジョンを入れ静置し, 粒子の沈 降により生ずる沈降界面の高さおよびェマルジョンの光 透過率より評洒した。 


\section{4 透析}

試料エマルジョン中からイオン性不純物を除去するた め, エマルジョンをセロファン紙で包み, 約 1 週間イオ ン交換水を 1 日数回取り換克て透析を行った.

\section{5 耐水性}

各種条件で調整されたエマルジョンをガラス板上に流 延し, 室温で風乾し, 厚さ約 $0.6 \mathrm{~mm}$ のフィルムを作 成した。このフィルムを $40^{\circ} \mathrm{C}, 10 \mathrm{mmHg}$ で 48 時間減 圧乾燥した後, $2 \times 4 \mathrm{~cm}$ に裁断し， $30^{\circ} \mathrm{C}$ のイオン交換 水中に放置して吸水率を求め, 耐水性を判定した。

\section{6 粒子表面荷電数の測定}

電気泳動U字管セルを使用し， $\mathrm{KOH}$ および $\mathrm{HCl}$ 水 溶液を緩衝液とし，既報2に従って行った。

\section{3 結果および考察}

\section{1 無乳化羭エマルジョンの合成}

\subsection{1 重合速度, 粒子の安定性に及ほす開始剤濃度 の影響}

一般に, 臨界ミセル濃度以下の乳化剂しか存在しない 疎水性モノマーの乳化重合采において，重合速度がきわ めて遅いことはよく知られている ${ }^{3)}$. 実際, 著者らは, KPS 開始剤として，乳化剂不在下でスチレンの乳化 重合を行ったが，その重合速度は大変遅かった1)。これ に対して, 著者らが本研究で問題としている親水性モ, マーである EA では, 果してどの程度の乳化重合速度 を示すかは, 興味もあり, かつ実際上でも重要である.

Fig. 1 に重合速度の結果を示した。図から明らかな ように，上述したスチレンの場合とは異なり， $90 \mathrm{mg} / l$ といら低開始剤濃度でも約 3 時間で重合が完結し, 濃度 の増大とともにその速度は速くなった.このように, EA の場合，乳化剂不在下でも普通の乳化重合速度が得られ

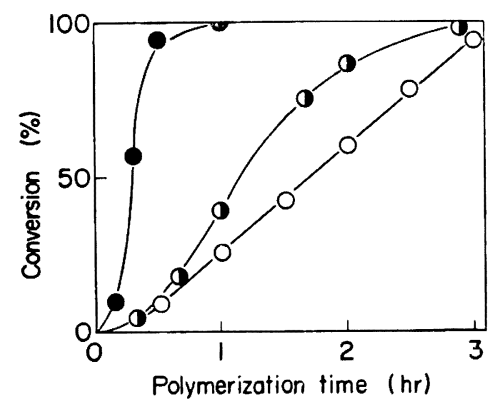

Fig. 1. Effect of the initiator concentration on the rate of emulsion polymerization of ethylacrylate in the absence of emulsifier.

Temp., $70^{\circ} \mathrm{C}$; agitation speed, $250 \mathrm{rpm}$; EA, 30 vol\%; KPS $(\mathrm{mg} / l): 0,90 ;$, 270; ๑, 3000 .

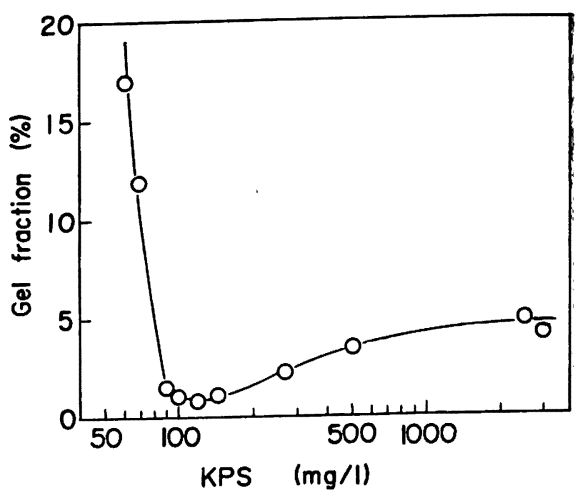

Fig. 2. Effect of the initiator concentration on the stability of emulsion polymerization.

EA, $30 \mathrm{vol} \%$; temp., $70^{\circ} \mathrm{C}$; agitation speed, $250 \mathrm{rpm}$.

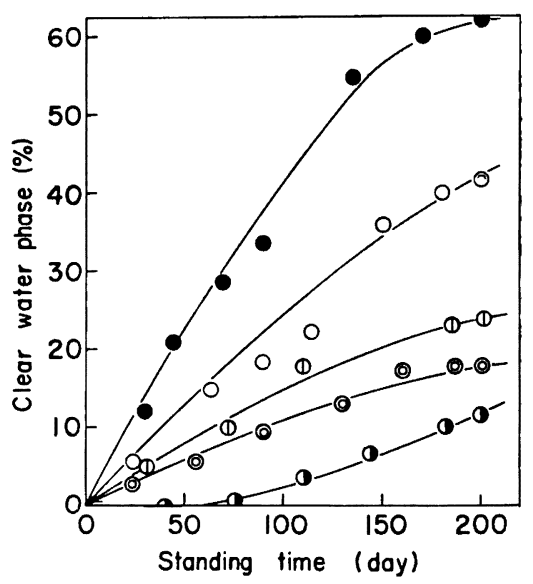

Fig. 3. Effect of the initiator concentration on the storage stability of emulsions.

Polymerization conditions: Temp., $70^{\circ} \mathrm{C}$; agitation speed, $250 \mathrm{rpm}$; EA, 30 vol \%; KPS (mg/l): $\bigcirc, 70 ;(1,90 ; \bigcirc, 120$; ○), $140 ; \bullet, 3000$.

ることが分かった、ただ，このような乳化重合系では， 主にかくはん棒に付着する形でゲル物が生成した。この ゲル物の生成はェマルジョンの安定性にとって, 最も重 要なことと思われたので, 緒言で述へたよらに, 安定性 に対して開始剤切片が有効に働くといら立場から開始剤 濃度を種々変え, 生成ゲル物量についてまず検討した。

Fig. 2 にその結果を示した。四から明らかなよらに, $120 \mathrm{mg} / l$ 付近までは開始剤濃度の増加とともに, ゲル 物量の減少, すなわち重合安定性の向上がみられたが, それ以上の濃度では逆にゲル物量は增大の傾向を示し た. 
乳化刋不在下でのポリアクリル酸エチルエマルジョンの合成とその皮膜の耐水性

Table 1. Number of surface charges of poly(ethyl acrylate) emulsions measured from electrophoresis.

\begin{tabular}{|c|c|c|c|c|c|c|c|}
\hline \multirow{2}{*}{ No. } & \multirow{2}{*}{$\begin{array}{c}\text { Particle diameter } \\
(\AA)\end{array}$} & \multirow{2}{*}{$\begin{array}{l}\text { Degree of poly- } \\
\text { merization (P) }\end{array}$} & \multirow{2}{*}{$\begin{array}{l}\text { Number of polymer } \\
\text { molecules in a } \\
\text { particle }\left(n^{\prime}\right)\end{array}$} & \multirow{2}{*}{\multicolumn{2}{|c|}{$\begin{array}{l}\text { Number of surface } \\
\text { charges }\left(n^{\prime \prime}\right)\end{array}$}} & \multirow{2}{*}{$\mathrm{KOH}^{n^{\prime \prime} / 1}$} & \multirow{2}{*}{ ' $\mathrm{HCl}$} \\
\hline & & & & & & & \\
\hline 1 & 3760 & 16000 & 12500 & 13100 & 10800 & 1.05 & 0.86 \\
\hline 2 & 2960 & 7430 & 13170 & 16730 & 10750 & 1.27 & 0.82 \\
\hline 3 & 2580 & 8220 & 7890 & 11270 & 8190 & 1.43 & 1.04 \\
\hline 4 & 1980 & 4680 & 6290 & 7240 & 5320 & 1.15 & 0.85 \\
\hline
\end{tabular}

* Buffer solution: Polymerization conditions: EA, $20 \mathrm{ml}$; water, $180 \mathrm{ml}$; temp., $70^{\circ} \mathrm{C}$; atmosphere, $\mathrm{N}_{2}$; agitation speed, $250 \mathrm{rpm}$, KPS (mg/l): No. 1, 500; No. 2, 500; No. 3, 1000; No. 4, 2000, Tween-20 (nonionic emulsifier, Kao Atras) (mg/l); No. 1, 0; No. 2, 100; No. 3, 100; No. 4, 100; conversion, $>98 \%$.

Table 2. Relationship between the initiator concentration and the number of surface charges of poly (ethyl acrylate) emulsion particle calculated from the degree of polymerization.

\begin{tabular}{cccc}
\hline $\begin{array}{c}\text { Initiator concentration } \\
(\mathrm{mg} / l)\end{array}$ & $\begin{array}{c}\text { Particle diameter } \\
(\AA)\end{array}$ & $\begin{array}{c}\text { Degree of poly- } \\
\text { merization }\end{array}$ & $\begin{array}{c}\text { Number of surface } \\
\text { charges }\end{array}$ \\
\hline 60 & 4300 & 41600 & 7210 \\
120 & 4160 & 32100 & 8470 \\
500 & 4600 & 22300 & 16500 \\
3000 & 5100 & 5200 & 96500 \\
\hline
\end{tabular}

Polymerization conditions: EA, $20 \mathrm{ml}$; water, $180 \mathrm{ml}$; temp., $70^{\circ} \mathrm{C}$; atmosphere, $\mathrm{N}_{2}$; agitation speed, $250 \mathrm{rpm}$; conversion, $>98 \%$.

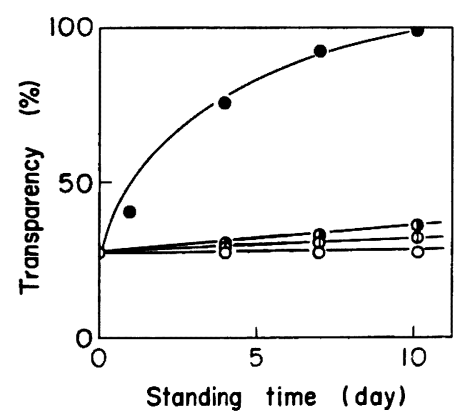

Fig. 4. Effect of the addition of potassium persulfate on the storage stability of emulsion.

Measured temp., $30^{\circ} \mathrm{C}$; KPS concn. of base PEA emulsion, $120 \mathrm{mg} / \mathrm{l}$. Amount of KPS added to emulsion $(\mathrm{mg} / \mathrm{l}): \bigcirc, 0$; (1) $20 ;$ I. $150 ; \bullet, 2880$.

Fig. 3 には, 放置安定性についての結果を示した. 四から明らかなよらに，重合安定性の場合とほぼ同様の 傾向を示しており，特に開始剤濃度の高い采ではエマル ションの放置安定性が著しく悪かった.

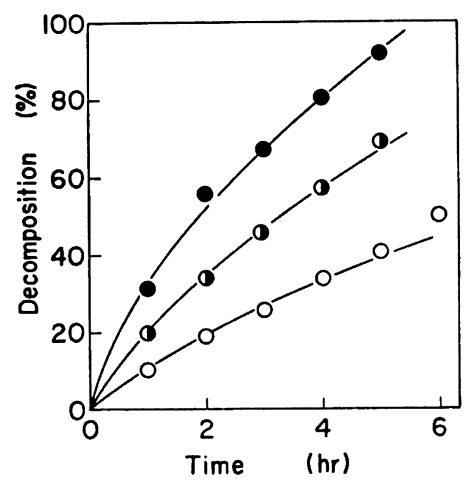

Fig. 5. Rate of the decomposition of potassium persulfate in aqueous solution at different temperatures.

KPS, $3.6 \times 10^{-2} \mathrm{~mol} / l$; atmosphere, $\mathrm{N}_{2}$; temp. $\left({ }^{\circ} \mathrm{C}\right): \bigcirc, 70 ; \bigcirc, 75 ; \bullet, 80$.

以上の結果より, 特定の開始剤濃度において乳化剂不 在下でも安定なエマルジョンの作製可能なことが分かっ た. なお, 通常の乳化重合では, 開始剤濃度として約 $500 \mathrm{mg} / l$ が用いられているが，上記各安定性におい 
Table 3. Effect of the polymerization temperature on the gel fraction and the mobility of emulsion particles.

\begin{tabular}{ccccc}
\hline \hline $\begin{array}{c}\text { Polymerization } \\
\text { temperature }\left({ }^{\circ} \mathrm{C}\right)\end{array}$ & $\begin{array}{c}\text { KPS } \\
(\mathrm{mg} / \mathrm{l})\end{array}$ & $\begin{array}{c}\text { Particle diameter } \\
(\AA)\end{array}$ & $\begin{array}{c}\text { Gel fraction } \\
(\%)\end{array}$ & $\begin{array}{c}\text { Mobility* } \\
\left(\mathrm{cm}^{2} / \mathrm{sec} / \mathrm{esu}\right)\end{array}$ \\
\hline 70 & 11 & 6100 & 17.0 & 0.06 \\
75 & 11 & 4650 & 8.1 & 0.11 \\
80 & 11 & 4300 & 1.35 & 0.18 \\
70 & 13 & - & 12.0 & - \\
75 & 13 & - & 5.6 & - \\
80 & 13 & - & 0.56 & - \\
\hline
\end{tabular}

* Buffer solution, $0.01 \mathrm{~N} \mathrm{HCl}$; emulsion concn.; $7.5 \mathrm{~g} / l$.

Polymerization conditions: EA, $30 \mathrm{vol} \%$; agitation speed, $250 \mathrm{rpm}$.

て良好な結果を与えた $120 \mathrm{mg} / \mathrm{l}$ は，その約 $1 / 4$ に相当 している.

ところで, 乳化刘不在下でのェマルジョン粒子の安定 化に関して，最近，重合中に生成するオリゴマーが乳化 剤的な作用をし，粒子の安定化に寄与しているのではな いかとする報告がみられる4). しかし，その場合には， 通常の乳化重合系よりも開始ラジカルの発生量が非常に 多く，オリゴマーの生成しやすい系で行われており，本 系の上らに逆に開始剂量がより少ない系では,このよう なオリゴマーによる粒子の安定化は無視できると考えら れる. 事実, 上記報告の中でみられたような重合系の泡 立ちといった現象は全く観察されなかった。このことか ら，本系における粒子の安定化は，緒言で述べたょう に，開始剤切片として粒子表面に存在すると思われる - $\mathrm{SO}_{4}$ - によると理解される。 このことは, 表面荷電を 与えない $\mathrm{H}_{2} \mathrm{O}_{2}$ を開始剂とした場合に，安定なェマルジ ョンが生成されなかったことからも支持された。そこ で，次に電気泳動法より $-\mathrm{SO}_{4}$ - 基に基づくと思われる 表面荷電数を测定した。

\subsection{2 エマルシション粒子表面荷電数}

Table 1 にその結果を示した。表から明らかなよう に, 粒子 1 個当たりの表面荷電数 $\left(n^{\prime \prime}\right)$ は, 粒子中のポ リマー分子数 $\left(n^{\prime}\right)$ にほぼ一致した。 このことは，ポリ アクリル酸メチル生長ラジカルが不均斉化停止を起こし やすいこど）考慮すれば，開始剤切片としてポリマー 末端に導入された - $\mathrm{SO}_{4}^{-}$基のほとんどが PEA 粒子表 面に固定されることを示している。なお，この点に関し て, 著者らはすでにポリスチレンおよびポリブチルアク リレート ${ }^{\text {() }}$ について同様の結果を得ている。 ところで, 緩衝液として $\mathrm{KOH}$ を用いて得られた荷電数の方が, $\mathrm{HCl}$ のそれよりも若干高い値を与兄ているが，これは $\mathrm{OH}^{-}$の吸着扰よび重合中に一部加水分解して生成され た7)カルボキシル基が $\mathrm{KOH}$ 緩衝液中では完全解離し, 荷電中に加算されたためであろう。このように, KPSを
開始剤として得られた PEA エマルジョン粒子表面に は，粒子中のポリマー分子数に相当する荷電の存在が明 らかになった。

Table 2 には, 上述の知見に基づき，各開始剤濃度で 作製したエマルジョンの表面荷電を, 粒子径および重合 度の測定値より算出した結果を示した。表から明らかな ように，開始剂濃度の增加とともに，単位面積当たりの 表面電荷数は增大する傾向にあった。 ただし，これはモ ノマー濃度 $10 \mathrm{vol} \%$ で重合したものの結果である。な ぜなら，30 vol\% で重合した (Fig. 1 3) ものでは, 開始剤濃度が低くなるにつれて，ベンゼンへの溶解性が 悪く, 不溶性部分 (極度の高分子量体のためと思われる) が増加したため, 粘度測定ができなかった。しかし, 開 始剤量が多くなるほど，粒子表面荷電数が多くなるの は，間違いなさそうである，ところで，粒子の安定性が この荷電数に依存することを考慮すれば, Fig. 2, 3 で示 した重合打よび放置安定性に拈ける開始剤濃度 $120 \mathrm{mg} /$ $l$ 以下の結果については合理的に説明可能であるが，そ れ以上の濃度における安定性の低下については,このよ らな表面荷電数の因子のみでは説明不可能である.この 点については次のように考えた，重合に使用された開始 郕は，その分解速度の結果 (Fig. 5 参照) から考之，す べてが重合に関与するわけではなく，一部は残存して $\mathrm{K}^{+}$および $\mathrm{S}_{2} \mathrm{O}_{8}{ }^{2-}$ として系中に存在する. 一般に, 電 解質物質がエマルジョン粒子を不安定化すること,つま り塩析剤として作用することはよく知られている。 した がって, 開始剤量を増加すれば, 粒子の表面荷電数が增 加し, 粒子は安定化させるが, 一方では逆に, 電解質む 增加し塩析作用が高まる. それゆ六, Fig. 2, 3 で示し たように, $120 \mathrm{mg} / l$ の開始剂濃度付近で最高の安定化 がもたらされたと考えられる。そこで，この点を明らか にするため, $120 \mathrm{mg} / \mathrm{l}$ の開始剂濃度で作製されたエマ ルジョンに KPS を添加し, その放置安定性に与える影 響を検討した。 


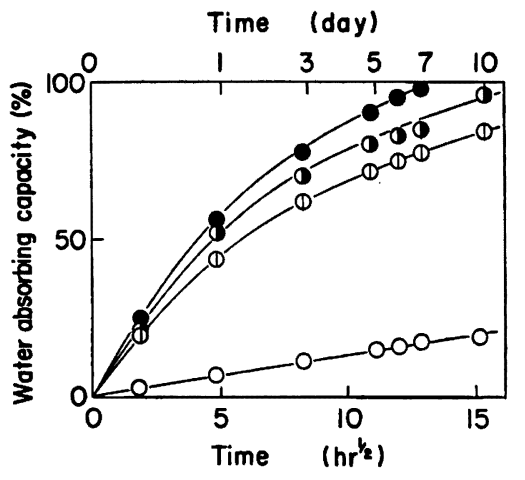

Fig. 6. Effect of the emulsifier on the water absorbing capacity of emulsion-films. Measured temp., $30^{\circ} \mathrm{C}$; KPS concn. of base emulsion, $120 \mathrm{mg} / l$; amount of sodium lauryl sulfate $(\mathrm{mg} / \mathrm{g}$ polymer): O, 0; $\mathcal{D}, 6 ; \bigcirc, 11.6 ; \bullet, 30$.

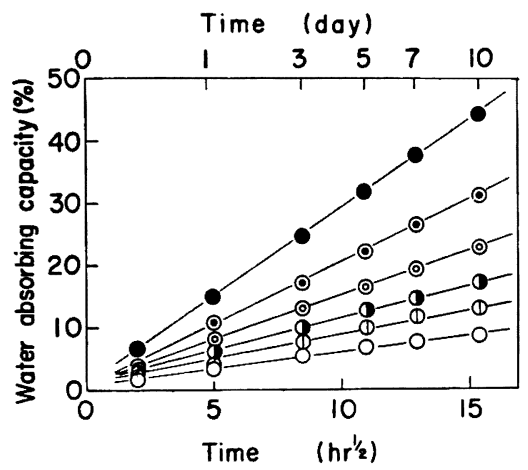

Fig. 7. Effect of the initiator concentration on the water absorbing capacity of emulsion-films.

KPS concn. of emulsions $(\mathrm{mg} / \mathrm{l}): \bigcirc, 70$; (1), 90; ๑, 120; ○, 140; $\odot, 270 ; \bullet, 3000$.

Fig. 4 にその結果を示した。四から明らかなよらに, KPS の添加量の增加に伴い, 放置時間とともに透過率 の上昇, すなわちエマルジョンの沈降が激しくなった。 また，逆に Fig. 3 において放置安定性の悪かった 3000 $\mathrm{mg} / \mathrm{l}$ の開始剂濃度で作製したエマルジョン中から透析 処理により不純物イオンを除去したところ, その放置安 定性は著しく向上した。これらの結果は上記した見解の 妥当であることを示している.

ところで, 上記の見解に従らならば, 開始剤の重合開 始反応にあずかる効率を高めてやれば，極端にいえば， 添加開始剂のすべてが重合の開始にあずかり, 水相に塩

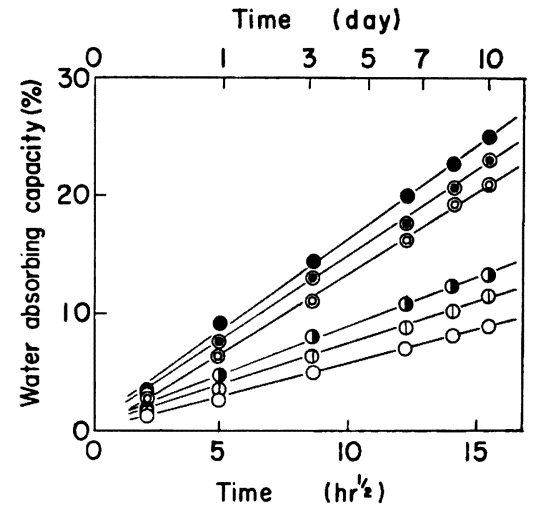

Fig. 8. Effect of the dialysis treatment of emulsion on the water absorbing capacity of emulsion-films.

KPS conc. of emulsions $(\mathrm{mg} / \mathrm{l}): \bigcirc, 70$; (1) $90 ; \bigcirc, 120 ; \odot, 140 ; \odot, 270$; 3000 .

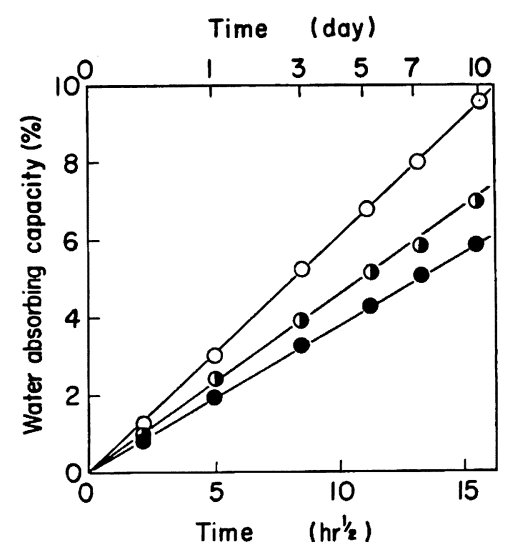

Fig. 9. Effect of the polymerization temperature on the water absorbing capacity of emulsion-films.

Measured temp., $30^{\circ} \mathrm{C}$; KPS concn. of emulsions, $120 \mathrm{mg} / l$; polymerization temp. $\left({ }^{\circ} \mathrm{C}\right): 0,70 ; 75 ; \bullet, 80$.

析剂として働くイオン性物質が生成しないようにしてや れば, 当然その安定性は增大するものと予想される。 そ こで, その方法として重合温度を高め, 重合中における 開始剂効率を増大させようとした。

\section{1.3 開始剤効率の影響}

Fig. 5 には，その実験に先立ち，70,75，および $80^{\circ} \mathrm{C}$ での KPS の分解速度を検討した結果を示した．因から 
明らかなように，これまでの重合条件である $70^{\circ} \mathrm{C} ， 5$ 時間では約 $60 \%$ が未分解で残存していることが分か る. しかし，分解温度を $75,80^{\circ} \mathrm{C}$ と高めることによ り,その速度は速くなり， $80^{\circ} \mathrm{C}$ では約 6 時間でほぼ分解 が完結した。 このような知見をもとに，次に Fig. 2, 3 であまり安定なエマルジョンが得られなかった開始剤濃 度 $11 \mathrm{mg} / l$ で重合を行い, 得られたェマルジョンの重合 および放置安定性を検討した。

Table 3 にその結果を示した，表から明らかなよう に, 重合温度が $70,75,80^{\circ} \mathrm{C}$ と高くなるに従い, 凝固 物量の低下は著しく，重合安定性はよくなった。また， 放置安定性も同様の傾向を示し, $80^{\circ} \mathrm{C}$ でのそれは, Fig. 3 で最も良好であった KPS 濃度 $120 \mathrm{mg} / l, 70^{\circ} \mathrm{C}$ の場 合にほぼ匹敵した (データ省略)。なお，Table 3 には 各エマルジョン粒子の易動度を併記したが（緩衝液およ びェマルジョンの濃度を一定した，いわゆる一点測定値 なので，表面電荷数で表示しなかった，高温になるほ ぞ, 易動度は大きく，仕込み KPS の重合開始への効果 が高くなっていることが分かる。これらの結果は，先述 した予想の妥当性を示すものであり, 無乳化剂高分子エ マルジョンの合成に関して，重要な知見が得られたこと になる.

\section{2 エマルジョンフィルムの耐水性}

前節において，いちおう乳化剤不在下においても実用 可能なエマルジョンが作製できることを明らかにした． 本節では, このような無乳化剤 PEA エマルジョンフィ ルムの耐水性について検討した。

\section{2.1 乳化剈の影響}

まず，乳化剤を含有しないことによる耐水性の向上の 程度を明確にしょらとした。そのため，無乳化剂 PEA エマルジョンおよびそれに通常アニオン性乳化㓮として 乳化重合に広く用いられているSLS を後添加したェマ ルジョンから作成したフィルムの吸水率を測定した。

Fig. 6 にその結果を示した. 四から明らかなよらに, 無乳化剂エマルジョンフィルムの吸水率が 10 日後䄪 $10 \%$ 程度であるのに対し, 乳化剤含有フィルムのそれ はその約 10 倍に達し，しかも SLS を多く含有するも のの方が吸水率は大きかった。このことは，通常いわれ ているよらに, 乳化剤の存在がエマルジョンフィルムの 耐水性を著しく低下させること, 言い換えれば, 無乳化 剤フィルムの耐水性の良好なことを示している.

\section{2.2 開始剤の影響}

乳化剂と同様，イオン性物質も耐水性低下の原因とな ることはよく知られている。 そこで，無乳化剤エマルジ ョンの耐水性に及注寸重合時の開始剤量の影響について 検討した.

Fig. 7 にその結果を示した。因から明らかなように, 開始剤濃度の減少とともに, 吸水率はめいり上うに低下
しており, 耐水性の向上が認められた，次に，各エマル ショョンを透析し, 水相の電解質物質を除去した後作成し たエマルシションフィルムの吸水率を測定した。

Fig. 8 にその結果を示した. Fig. 7 の結果と比較して 明らかなように, 水相の電解質物質の除去により, 吸水 率は低下しており, 特に開始剤濃度が高い系 $(3000 \mathrm{mg} /$ $l)$, 寸なわち透析前に水相中に多量の電解質を含んでい た采泣，その低下は顥著であった。このことは, 開始 剤に由来する水相のイオン物質の吸水量が非常に大きい ことを示している. しかし, 開始剤濃度の影響はやはり 観察された。この点に関しては, 先述したように, 開始 剤濃度が高くなるほど, 一 $\mathrm{SO}_{4}$ - 末端基が增大すること, 重合度が低下寸ること(これはポリマー分子の弾性率が 低下してくるので，水分子が皮膜内へ漫透しやすくな る ${ }^{8)}$ ), および加水分解により生成されるカルボキシル基 の增大 ${ }^{9)}$ によるものと考觉られる。

Fig. 9 には, Table 3 において開始剤濃度一定で, 重合温度を变化させて作製したェマルジョンフィルムの 吸水率の結果を示した，図から明らかなよらに，高温で 重合したエマルジョンフィルムほど，吸水率は小さく耐 水性は良好であった (なお，Fig. 7 9 の吸水率 (縦軸) の尺度が異なることに注意)。このことは，- $\mathrm{SO}_{4}$ - 末端 による吸水よりも，KPS の末分解物扰よび分解副生成 物の方が強い吸水因子になることを示しており，Fig. 8 の結果ともよく一致する.

以上の結果から, KPS の重合開始効率を高め, 粒子 表面電荷数を增加させるとともに水相中のイオン性物質 量を少なくすることにより, 良好な耐水性皮膜を与え, かつ安定な無乳化戍 PEA エ、ルジョンを作製できるこ とが明らかなった。

\section{文献}

1) 松本恒隆, 越智明宏: 高分子化学, 22, 481 (1965).

2) 松本恒隆, 嵨田 勝: 同上, 22, 172 (1965).

3) W. V. Smith, R. H. Ewart: J. Chem. Phys., 16, 592 (1948).

4) 山崎信助：第 22 回高分子討論会講演要旨集, I-315 (1973, 東京).

5) C. H. Bamford, A. D. Jenkins: Nature, 176, 78 (1955).

6) 松本恒隆, 寺島 宏: 第 14 回高分子研究発表 会講演要旨集, p. 38 (1968, 神戸).

7) S. Muroi: J. Appl. Polym. Sci., 10, 713 (1966).

8) S. Muroi: Bull. Chem. Soc. Japan, 39, 2295 (1966).

9）松本恒隆, 大久保政芳, 尾上 勧: 未発表. 